\title{
Epidemiology of Mycoplasma agalactiae and Mycoplasma mycoides cluster in flocks of northeastern Brazil
}

\author{
Sandra Batista dos Santos ${ }^{{ }^{*}} \odot$ Renata Pimentel Bandeira de Melo ${ }^{1}$ \\ Luana Thamires Rapôso da Silva ${ }^{1}$ Júnior Mário Baltazar de Oliveira ${ }^{1}$ \\ Atzel Candido Acosta Abad ${ }^{1}$ José Wilton Pinheiro Júnior ${ }^{1} \odot$ Rinaldo Aparecido Mota $^{1}$
}

${ }^{1}$ Universidade Federal Rural de Pernambuco (UFRPE), 52171-900, Recife, PE, Brasil. E-mail: sanbsantos@gmail.com. *Corresponding author.

\begin{abstract}
The present study aimed to investigate contagious agalactia (CA) in flocks from Pernambuco State. The study involved 225 goats and 63 ewes; 288 milk samples and 100 vaginal swabs were collected in total. The PCR assays were carried out using specific primers to Mycoplasma agalactiae and the Mycoplasma mycoides cluster. Among the goat's milk samples, 12.0\% (27/225) were positive for Mycoplasma agalactiae DNA, while 5.3\% (12/225) contained the Mycoplasma mycoides cluster. Of the vaginal swabs taken from goats, 15.4\% (12/78) were positive for Mycoplasma agalactiae DNA and 3.8\% (3/78) contained the Mycoplasma mycoides cluster. In the case of ewes, 4.3\% (1/23) of the milk samples contained Mycoplasma agalactiae DNA, and 7.5\% (3/40) were positive for the Mycoplasma mycoides cluster. Vaginal swabs taken from sheep's were negative. Analysis of risk factors for mycoplasmosis, showed that goats and sheep flocks on the extensive breeding system are more likely to have mycoplasmosis than those on the intensive breeding system (odds ratio (OR) $6.2 ; p=0.004) ;$ meat goat and sheep flocks are more likely to have infection compared to dairy flocks (OR 4.8; $p=0.011) ;$ unclean animal housing increases the chances of infection (OR 5.0; $p=0.031)$ and not performing quarantine increases the chances of mycoplasmosis (OR 4.6; $p=0.042)$. Based on these findings we conclude that CA syndrome in the semiarid region of Pernambuco state can be associated with Mycoplasma agalactiae and Mycoplasma mycoides cluster.
\end{abstract}

Key words: contagious agalactia, flocks, diagnostic, epidemiology, risk factor.

Epidemiologia de Mycoplasma agalactiae e Mycoplasma mycoides cluster em rebanhos do nordeste do Brasil

RESUMO: $O$ objetivo deste estudo foi investigar a Agalaxia contagiosa em rebanhos do estado de Pernambuco. Foram examinadas 225 cabras e 63 ovelhas, das quais foram colhidas 288 amostras de leite e 100 suabes vaginais. Foram realizadas reações da PCR com iniciadores especificos para Mycoplasma agalactiae e Mycoplasma mycoides cluster. A frequência total de Mycoplasma agalactiae em amostras de leite caprino foi de 12,0\% (27/225) e de 5,3\% (12/225) para Mycoplasma mycoides cluster. Dos suabes vaginais de cabras as frequências detectadas na PCR foram de 15,4\% (12/78) para Mycoplasma agalactiaee 3,8\% (3/78) para Mycoplasma mycoides cluster. Em leite de ovelhas a frequência de Ma foi de 4.3\% (1/23) e de 7,5\% (3/40) para Mycoplasma mycoides cluster. Na análise dos fatores de risco para micoplasmoses verificou-se que rebanhos de caprinos e ovinos mantidos no sistema extensivo são mais prováveis de adquirir micoplasmose quando comparados com o sistema intensivo (odds ratio (OR) 6,2; $p=0,004$ ); rebanhos de caprinos e ovinos de corte são mais prováveis de adquirir micoplamsose do que rebanhos de leite (OR 4,8; $p=0,011)$; não realizar limpeza das instalações aumenta as chances de infecção (OR 5,0; $p=0,031)$; não realizar quarentena aumenta as chances das micoplasmoses estudadas $(O R$ 4,6; $p=0,042)$. Conclui-se que M. agalactiae e Mycoplasma mycoides cluster estão envolvidos na síndrome de CA em rebanhos de caprinos e ovinos do semiárido pernambucano.

Palavra-chave: agalaxia contagiosa, rebanhos, diagnóstico, epidemiologa, fatores de risco.

\section{INTRODUCTION}

Contagious agalactia (CA) is an infectious disease that affects goats and sheep. It is characterized by mastitis-agalactia, arthritis, and keratoconjunctivitis. Outbreaks of CA have been reported in several wild ruminants (CHAZEL et al., 2010; OSTROWSKI et al., 2011). The disease is caused by Mycoplasma agalactiae (Ma), as well as by several species in the Mycoplasma mycoides (M. mycoides) cluster; namely, Mycoplasma capricolum subsp. capricolum (Mcc), Mycoplasma 
mycoides subsp. capri (Mmc), and Mycoplasma putrefaciens $(M p)$. All of these pathogens cause indistinguishable clinical symptoms (OIE, 2013). Of these, $M p$ was included in the phylogenetic M. mycoides cluster by MANSO-SILVÁN et al. (2007). The M. mycoides cluster has complex taxonomy and includes the causative agents of contagious caprine pleuropneumonia and contagious bovine pleuropneumonia. In addition, it encompasses the bovine pathogen $M$. leachii and the small ruminant pathogens $M m c$ and $M c c$ (FISCHER et al., 2012).

The $M a$ primarily affects the mammary glands, eyes, joints, and less frequently the respiratory tract. In contrast, the other species mentioned are primarily related to respiratory diseases (NICHOLAS, 2002). Congenital infections have been reported in newborn goatling in Brazil, confirming that $M a$ is transmitted across the placenta (SILVA et al., 2014). Furthermore, several authors have suggested that $M a$ in goats is transmitted venereally (GIL et al., 2003; AMORES et al., 2011; GÓMEZ MARTÍN et al., 2012). In sheep, $M a$ is the most common causative agent of $\mathrm{CA}$; although, $\mathrm{Mmc}$ also occurs sporadically. Conversely, goat CA is more complex, four species can cause the disease (Ma, Mcc, Mmc and $M p$ ), and mixed infections have been reported in the Mediterranean region (GÓMEZ MARTÍN et al., 2012; GÓMEZ MARTÍN et al., 2013). More specifically, the $M m c$ and $M c c$ species cause 'MAKePS' syndrome, (mastitis, arthritis, keratitis, pneumonia, and septicemia), while $M p$ mainly causes mastitis and arthritis (PEYRAUD et al., 2003).

The epidemiology and geographical distribution of CA remain unclear in South America. In Brazil specifically, only a few authors have reported CA outbreaks in goats and sheep (NASCIMENTO et al., 1986; AZEVEDO et al., 2006). Nonetheless, as control measures have failed, the disease has spread to many regions of the country. The present study constitutes an epidemiological and molecular investigation of CA causing agents in semiarid mesoregions in the state of Pernambuco, northeastern Brazil.

\section{MATERIALS AND METHODS}

This investigation was conducted across eleven properties in semiarid regions with a high concentration of goat and sheep stocks. The target districts were as follows: Serra Talhada (two goat farms, A and B, and one sheep farm, C), Sertânia (five farms of Saanen and Toggenburg dairy goats maintained in intensive production management,
D, E, F, G, and H), Custódia (one goat farm, I), and Floresta (one sheep farm, $\mathrm{J}$ and one goat farm, $\mathrm{K}$ ).

After visual inspection of the animals, 225 goats' and 63 ewes' milk samples and 100 vaginal swabs were collected, regardless of the animals' clinical symptoms. To collect the milk samples, the ostium ceiling was flushed with water and soap, dried with wipes, and sterilized with $70 \%$ alcohol. Next, numbered, sterile vials were used to collect $5 \mathrm{~mL}$ of milk from each mammary gland. In addition, 100 vaginal swabs in total were collected from 78 goats and 22 ewes using sterile swabs rubbed on the lateral and internal walls of the vagina. These were then stored in tubes containing $2 \mathrm{~mL}$ of sterile phosphate-buffered saline (pH 7.2).

The milk and vaginal swabs were then refrigerated at $4{ }^{\circ} \mathrm{C}$ and transported to the Laboratory of Infectious Diseases (LDIC/DMV/ UFRPE), where they were submitted to DNA extraction using commercially available kits (Wizard SV Genomic DNA purification System ${ }^{\circledR}$; Promega Corporation, Madison, WI, USA; Ref. A2361 for the milk samples and Ref. A1125 for the vaginal swabs). These kits were used according to the manufacturer's instructions; although, some adjustments were made. Quantity and quality of the extracted DNA were evaluated using an automatic quantifier (Multiscan $\mathrm{Go}^{\circledR}$; ThermoScientific). Next, PCR assays were carried outusing specific primers for $M a$ (FS1:5'AAAGGTGCTTGAGAAATGCC-3' and FS2: 5' -GTTGCAGAAGAAAGTCCAATCA-3', which amplify a 375-bp fragment) and for the Mycoplasma mycoides cluster (F-REAP:5'GAAACGAAAGATAATACCGCATGTAG-3' and R-REAP:5'-CCACTTGTGCGGGTCCCCGTC-3', which amplify a 785-bp fragment).

The PCR reaction used a thermal profile that has been previously described, with some adjustments (TOLA et al., 1997; PERSSON et al., 1999). A reaction mix was prepared containing $5 \mu \mathrm{L}$ of DNA template, $30 \mathrm{pmol}$ of each primer, $6.25 \mu \mathrm{L}$ of GoTaq $^{\circledR}$ Green Master Mix (Promega ${ }^{\circledR}$ Corporation, Madison, WI, USA; Ref. M7122) and Milli-Q ultrapure water up to $25 \mu \mathrm{L}$, in accordance with the manufacturer's instructions. Mycoplasma mycoides subsp.capri (GM12) DNA was used as a positive control in the M. mycoides cluster reactions, as well as in the reactions for a Mycoplasma agalactiae strain isolated in Paraiba State (BrPB01; Gen Bank No.JQ612164;0.8ng/ $\mu \mathrm{L})$. Reactions were carried out in a thermocycler (Bioer XP Thermal Cycler ${ }^{\circledR}$; 
Bioer Technology Corporation Ltda., Hangzhou, China). Products were then analyzed in $1.5 \%$ electrophoresis gel, and the amplicons visualized in a transilluminator (L-Pix; LocusBiotechnology ${ }^{\circledR}$ ) and photographed.

The genomic DNA samples obtained in the PCR were purified using a commercial kit, MegaQuick-spin ${ }^{\mathrm{TM}}$ Total Fragment DNAPurification Kit (Intron Biotechnology ${ }^{\circledR}$, Korea). Subsequently the DNA was quantified using an automatic quantifier for quality and quantity measurement. Purified products after amplification were bidirectionally sequenced using the BigDyeTerminator v3.1 Cycle Sequencing kit (Applied Biosystems, USA), according to the manufacturer's instructions. The primers used for the sequencing were the same as used in the amplification step.

Milk and vaginal swab samples that were positive for mycoplasma DNA in the PCR were processed for mycoplasma isolation. In the case of milk samples, $2 \mathrm{~mL}$ was sterilized using a syringe coupled with a membrane filter $(0.45 \mu \mathrm{M})$, and $100 \mu \mathrm{L}$ of the filtrate was diluted to concentrations of $10^{-1}$ to $10^{-5}$ and inoculated onto liquid and solid modified Hayflick's medium. These samples were incubated at $37^{\circ} \mathrm{C}$ for 21 days, and the agar plates were then placed in a microaerophilic jar. Growth in the plates was verified using a stereomicroscope $(80 \times$ magnification $)$. Mollicute isolates were confirmed using a Dienes probe, and Mycoplasma genera were identified with a digitonin sensitivity test (WHITFORD et al., 1994; RAZIN \& TULLY, 1996).

Epidemiological questionnaires were used to obtain information about the type of farming and management practices and thus identify possible risk factors in each herd. The questionnaires were delivered by a single trained investigator and answered by personnel who could provide information about the animals'nutrition, reproduction, and milking system. Variables investigated and their respective answer categories were as follows: consortium creation (yes/no); herd type (dairy/dairy and meat); wetlands on the property (yes/no); flooded areas on surrounding properties (yes/no); presence of hematophagous insects (yes/no); insect control (yes/no); presence of quarantine (yes/no); reproductive management (natural breeding/artificial insemination/both). Univariate analysis of infection-associated risk factors was performed using the Pearson chisquare test $\left(\chi^{2}\right)$ or Fisher's exact test. A logistic regression analysis was then performed, which considered the "Gold standard" PCR result for mycoplasmas ( $M a$ or $M$. mycoides cluster) as the dependent variable. Independent or explanatory variables with a p-value $<0.20$ were considered in the model, so that no possible event risk factors were excluded from the analysis (HOSMER \& LEMESHOW, 1989). EpiInfo $7^{\mathrm{TM}}$ software was used to perform statistical calculations; the significance level was set at $5.0 \%$.

\section{RESULTS}

In this study, Mycoplasmataceae were detected using PCR in farms from semiarid mesoregions. Figure 1 shows gel electrophoresis of PCR results for $\mathrm{Ma}$ and $M$. mycoides cluster. We found that $18.2 \%(41 / 225)$ of goats and $6.3 \%(4 / 63)$ of sheep were positive for Mycoplasmataceae DNA. On each farm, the $M a$ results were as follows: $\mathrm{A}-63.6 \%, \mathrm{~B}-17.6 \%, \mathrm{C}-4.0 \%$, and $\mathrm{K}-8.3 \%$. The M. mycoides cluster results on the individual farms were: $\mathrm{E}-25.0, \mathrm{H}-7.7, \mathrm{I}-11.7$, $\mathrm{J}-7.5$, and $\mathrm{K}-10.0$. Figure 2 shows the frequency of $M a$ and $M$. mycoides cluster on each farm, as detected by PCR analysis.

Throughout all districts, the frequencies of $M a$ and $M$. mycoides cluster in goats' milk samples were $12.0 \%$ and $5.3 \%$, respectively; table 1 shows the results in the individual districts. In the goat vaginal swabs, the frequency of $M a$ was $15.4 \%(12 / 78)$, while that of the $M$. mycoides cluster was $3.8 \%(3 / 78)$. The highest $M a$ frequency in goat vaginal swabs (30.0\%) occurred in the Serra Talhada district. In ewes' milk, $M a$ was detected in $4.3 \%$ $(1 / 23)$ of samples, while the M. mycoides cluster was found in $7.5 \%(3 / 40)$. Ewes' vaginal swabs were all negative for Mycoplasmataceae in the PCR analysis. Among farms that shared an owner, some signals of CA were reported, such as polyarthritis $(19.2 \%)$, sudden drop in milk production $(11.8 \%)$, and reproductive disorders (17.9\%). It was possible to confirm the viability of the bacteria, by isolation in milk, where by mollicutes grew in $26.7 \%$ of the goats' milk samples.

In the subsequent analysis, the main risk factor for $\mathrm{CA}$ was the extensive system of goat breeding, which carried a higher risk of mycoplasmosis than the intensive system $(\mathrm{OR}=$ $6.2 ; \mathrm{p}=0.004)$. Furthermore, meat flocks were more likely to carry infection than dairy flocks (OR = $4.8 ; \mathrm{p}=0.011)$. Failure to clean the animals' housing increases the risk of infection $(\mathrm{OR}=5.0 ; \mathrm{p}=0.031)$, as does failure to perform quarantine $(\mathrm{OR}=4.6$; $\mathrm{p}=0.042$; Table 2). 


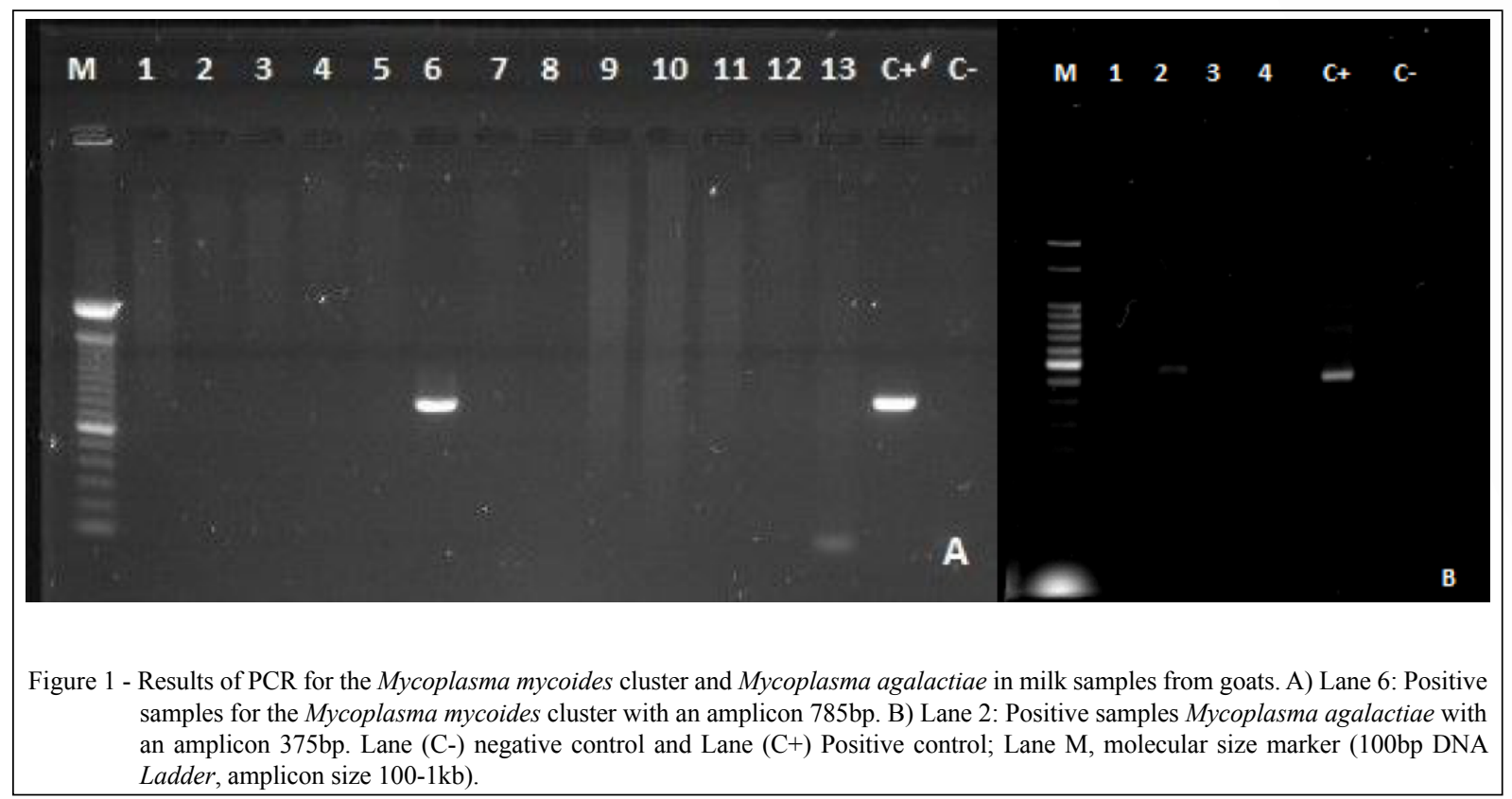

\section{DISCUSSION}

$\mathrm{CA}$ is a significant infectious disease among goat and sheep flocks, which limits production on both dairy and meat farms. In the present study, the prevalence of CA in goats, as expected, corroborated previously published data from endemic areas of northeastern of Brazil, which range from $20 \%$ to $56.43 \%$ of infection (BANDEIRA et al., 2008). In contrast, using serological analysis during CA outbreaks among goats in the Paraiba State, CAMPOS et al. (2009) reported a higher prevalence of $83.2 \%$. In ewes and lambs; however, the prevalence of infection varies. For instance, in a CA outbreak in Paraiba State, the morbidity rate was of $26 \%$ in goats and $49 \%$ in lambs, with a total prevalence of $100 \%$ (AZEVEDO et al., 2006). In France, CHAZEL et al., (2010) reported agalactia is most often caused by $M m c, M c c$, and $M p$ in goats, whilst in sheep, $M a$ is the most common causative species. In Spain, ARIZAMIGUEL et al. (2012) reported that the prevalence of CA in sheep varied from $50 \%$ to $100 \%$ on different farms; in Jordan, AL-MOMANI et al. (2008) reported a prevalence of $39 \%$ in sheep and $36 \%$ in goats.

Distribution of $M a$ among dairy sheep and goats varies in different locations. In Spanish dairy sheep farms, $M a$ is the most common causative factor, while the M. mycoides cluster is reported most often in goat flocks (ARIZA-
MIGUEL et al., 2012). In the present study, we reported that both $M a$ and the $M$. mycoides cluster circulate freely in goat and sheep flocks. More specifically, conditions that favor spread include keeping animals in mixed flocks, poor sanitary conditions, and inadequate facilities. For instance, the high prevalence of CA in farm A was likely due to poor sanitary management, which contributes to the spread of $M a$ and $M$. mycoides cluster. On the same farm, the farmer had a history of managing flocks with CA. Among all the farms investigated, the most common causes of CA among meat goats and sheep were poor sanitary conditions and inadequate facilities. In farms that used an intensive breeding system, the probable prevalence of the $M$. mycoides cluster was $25 \%$, and it was common to exhibit and trade animals without disease control.

AL-MOMANI et al. $(2008 ; 2011)$ reported that the seroprevalence values of $M a$ among sheep, goats, and mixed flocks are $25 \%, 21 \%$, and $30 \%$; those of the $M m c$ were $32 \%, 38 \%$, and $34 \%$ in the same study, suggesting that these mycoplasmas circulate widely among flocks of sheep and goats that are kept together in mixed farms. Similar circumstances occur in the semiarid regions of northeastern Brazil. Using PCR, ALVES et al. (2013) reported $M a$ frequencies of 17.9 in goat semen and $3.7 \%$ in goats' milk. In the present study we identified a higher frequency of $30 \%$ among milk samples of goats. 


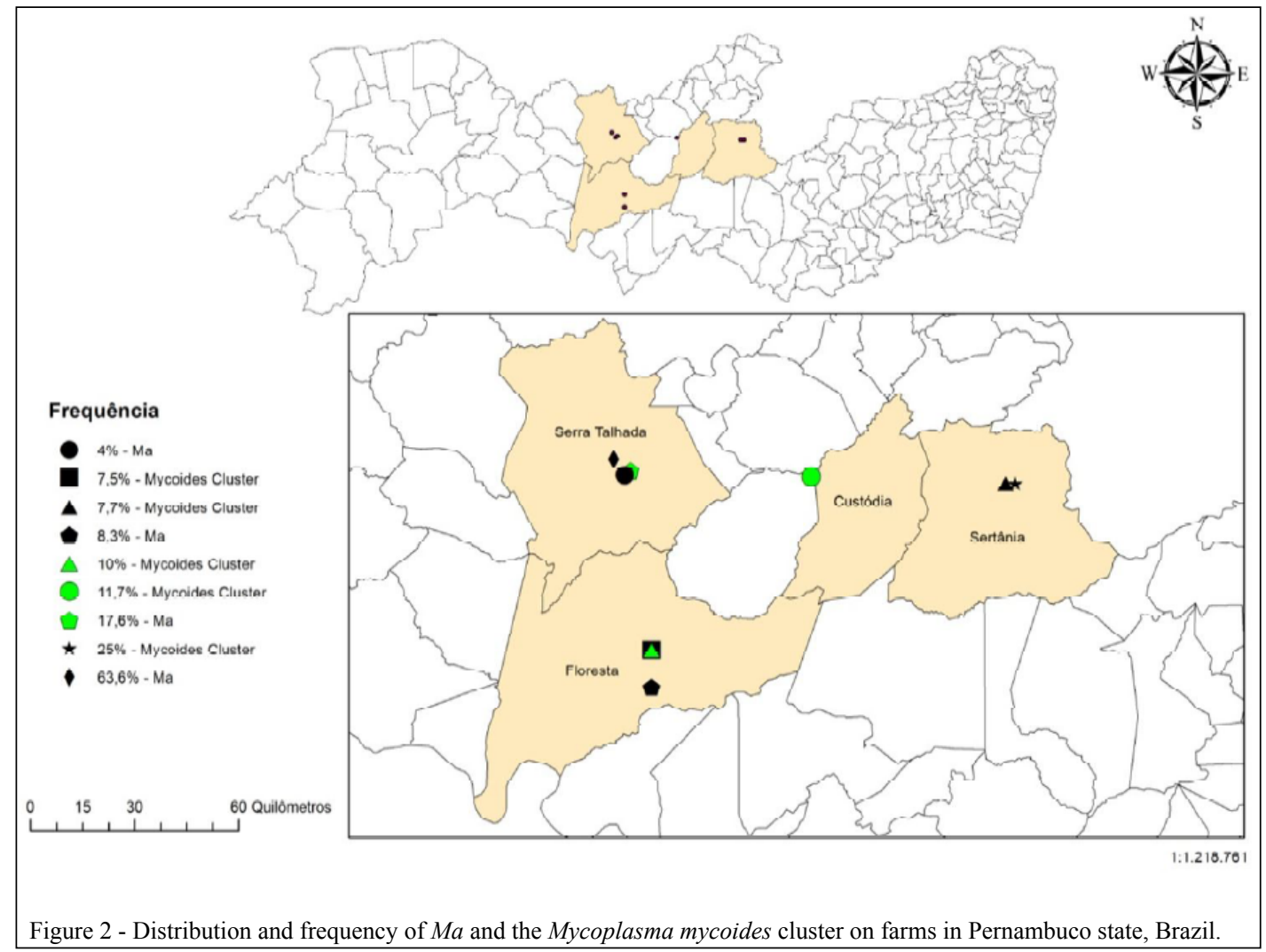

On a separate note, outbreaks of respiratory syndrome do occur among goats in Brazil. These outbreaks are associated with mastitis, arthritis, and keratoconjunctivitis caused by $\mathrm{Mmc}$ (NASCIMENTO et al., 1986). The present study corroborated these results by identifying Mycoplasma mycoides cluster in areas endemic for CA. Furthermore, the risk factors for $M a$ and the M.mycoides cluster were as follows: extensive breeding system, type of flock (meat), and failure to clean animal housing or perform quarantine. In their study of risk factors for $M a$ seroprevalence among sheep and goats, AL-MOMANI et al. (2008) demonstrated that only three variables increased $M a$ risk: use of outside rams, improper cleaning of the milking utensils, and separation of young from their mother. Failure to perform quarantine increased the risk of mycoplasmosis. NICHOLAS (1999) reported a similar correlation in the use of rams from other flocks for breeding which was accompanied by increasing seroprevalence of $M a$.

Similarly, cleaning of milking utensils should decrease infection by $M a$; accordingly, the

Table 1 - Results of PCR for Ma and the Mycoplasma mycoides cluster in goats from northeastern Brazil.

\begin{tabular}{lcccc}
\hline Districts & Ma & Milk & (Goat) & Vaginal swab \\
& & Myc. mycoides Cluster & Ma & Myc. mycoides Cluster \\
Custódia $(\mathrm{n}=34)$ & 0 & $3 / 34(8.8)$ & 0 & 0 \\
Floresta $(\mathrm{n}=60)$ & $5 / 60(8.3)$ & $6 / 60(10.0)$ & 0 & 0 \\
Serra Talhada $(\mathrm{n}=73)$ & $22 / 73(30.0)$ & 0 & $12 / 73(16.4)$ & $3 / 73(4.1)$ \\
Sertânia $(\mathrm{n}=58)$ & 0 & $3 / 58(5.2)$ & 0 & 0 \\
Total & $27 / 225(12.0)$ & $12 / 225(5.3)$ & $12 / 78(15.4)$ & $3 / 78(3.8)$ \\
\hline
\end{tabular}

Ciência Rural, v.48, n.4, 2018. 
Table 2 - Risk factors for mycoplasmosis in the goat and sheep flocks investigated.

\begin{tabular}{|c|c|c|c|c|c|}
\hline Variables & $\mathrm{N}$ & Mycoplasmosis & $\mathrm{P}$ value logistic regression & OR (I.C. 95\%) & $P$ value \\
\hline \multicolumn{6}{|c|}{ PCR } \\
\hline Intensive & 58 & $3(5.2 \%)$ & I rearing---.--..-- & - & 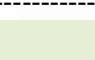 \\
\hline Semi-intensive & 60 & $8(13.3 \%)$ & $0.003^{(\mathrm{A})^{*}}$ & $2.8(0.7-11.2)$ & 0.140 \\
\hline Extensive & 107 & $27(25.2 \%)$ & & $6.2(1.8-21.4)$ & $0.004^{*}$ \\
\hline Meat & 167 & $35(20.9 \%)$ & 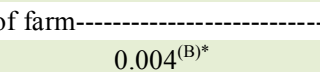 & $4.8(1.4-14.4)$ & $0.011^{*}$ \\
\hline Milk & 58 & $3(5.2 \%)$ & & & \\
\hline \multicolumn{6}{|c|}{ } \\
\hline$<50$ animals & 54 & $15(27.8 \%)$ & & & \\
\hline Between $51-100$ animals & 26 & $2(7.7 \%)$ & $0.034^{(\mathrm{B})^{*}}$ & & \\
\hline Above $>101$ animals & 145 & $21(14.5 \%)$ & & & \\
\hline \multicolumn{6}{|c|}{ 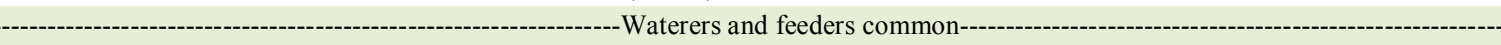 } \\
\hline Yes & 199 & $36(18.1 \%)$ & $0.266^{(\mathrm{B})}$ & & \\
\hline No & 26 & $2(7.7 \%)$ & & & \\
\hline \multicolumn{6}{|l|}{-----} \\
\hline Yes & 26 & $2(7.7 \%)$ & $0.266^{(\mathrm{B})}$ & & \\
\hline \multirow{2}{*}{\multicolumn{6}{|c|}{$36(18.1 \%)$}} \\
\hline & & & & & \\
\hline Weekly & 40 & $2(5.0 \%)$ & & - & \\
\hline Monthly & 18 & $1(5.5 \%)$ & $0.022^{(\mathrm{A})^{*}}$ & $1.1(0.1-13.2)$ & 0.929 \\
\hline No & 167 & $35(20.9 \%)$ & & $5.0(1.1-21.9)$ & $0.031^{*}$ \\
\hline \multicolumn{6}{|c|}{ - } \\
\hline Yes & 40 & $2(5.0 \%)$ & $0.033^{(\mathrm{B})^{*}}$ & & \\
\hline No & 185 & $36(19.4 \%)$ & & $4.6(1.0-19.9)$ & $0.042^{*}$ \\
\hline \multicolumn{6}{|c|}{ } \\
\hline Yes & 199 & $36(18.1 \%)$ & $0.266^{(\mathrm{B})}$ & & \\
\hline No & 26 & $2(7.7 \%)$ & & & \\
\hline & & ------Fate of & k animals------------------- & $-4-4$ & \\
\hline Slaughter & 134 & $27(20.1 \%)$ & & & \\
\hline Commerce & 14 & $0(0.0 \%)$ & $0.120^{(\mathrm{A})}$ & & \\
\hline Treatment & 77 & $11(14.3 \%)$ & & & \\
\hline
\end{tabular}

${ }^{(\mathbf{A})}$ Chi-square test ${ }^{(\mathbf{B})}$ Fisher's exact test; N - Total samples; OR - Odds Ratio; I.C. - Confidence Interval; ${ }^{1}$ Database used: (n=80); "Significant association to the level of $5.0 \%$.

present study demonstrated that failure to clean the animal housing was a risk factor for CA. ALMOMANI et al. (2008) reported that such improper practices may disseminate $M a$ and increased the number of infected animals in the flock. According to AL-MOMANI et al. (2010), the risk factors for $M m c$ were exacerbated by concentrated grazing supplements, $M m c$ seropositivity, and stress caused by changes in husbandry, nutrition, and climate, which is seen as a major factor among outbreaks in adults.

In the dry season, poor sanitary management and nutrition may promote the spread of $M a$ and the $M$. mycoides cluster by inhaled aerosol among sheep and goats, particularly if the animals are kept together (MADANAT et al., 2001;AL-MOMANI et al., 2008). A similar situation may occur in semiarid regions of northeastern Brazil. Thus, $M a$ and the $M$. mycoides cluster should be monitored in this group in particular, as these infections are important for animal health and publications. Moreover, $M a$ and $M$. mycoides cluster species cause serious, unexpected economic losses to northeastern Brazil.

\section{CONCLUSION}

In this context, it was possible to conclude that $M a$ and $M$. mycoides cluster species occur in high rates in semiarid areas of Pernambuco State. 
Inadequate facilities and extensive breeding enhance the risk of CA and other mycoplasmosis.

\section{ACKNOWLEDGMENTS}

We received financial support from Conselho Nacional de Desenvolvimento Científico e Tecnológico (CNPq) (Post doctoral; Process No. 158980/2 112 014-0).

\section{BIOETHICS AND BIOSECURITY COMMITTEE APPROVAL}

This research was submitted to the ethics committee for animal research (CEUA-UFRPE; No.23082.007834/2015-73).

\section{DECLARATION OF CONFLICTING INTERESTS}

The authors declare no conflicts of interest.

\section{REFERENCES}

AL-MOMANI, W. et al. Risk factors associated with Mycoplasma agalactiae infection of small ruminants in northern Jordan. Preventive Veterinary Medicine, v.83, p.1-10, 2008. Available from: $<\mathrm{https} / / \mathrm{www}$. sciencedirect.com/science/article/pii/S0167587707001833?via\%3Dihub>. Accessed: Oct. 5, 2016. doi: 10.1016/j.prevetmed.2007.08.003.

AL-MOMANI, W. et al. Seroprevalence of and risk factors for Mycoplasma mycoides subspecies capri infection in small ruminants in Northern Jordan. Tropical Animal Health and Production, 2010. Available from: $<$ https://www.researchgate.net/publication/47500597>. Accessed: Oct. 6, 2016. doi: 10.1007/s11250-010-9717-9.

ALVES, B.H.L.S. et al. Mycoplasma agalactiae in semen and milk of goat from Pernambuco State, Brazil. Pesquisa Veterinária Brasileira, v.33, p.1309-1312, 2013. Available from: <http://www. scielo.br/scielo.php?pid=S0100-736X2013001100004\&script $=$ sci arttext\&tlng=es $>$. Accessed: Oct. 10, 2016: doi: 10.1590/S0100736X2013001100004.

AMORES, A.J. et al. Presence of contagious agalactia causing mycoplasmas in Spanish goat artificial insemination centres. Theriogenology, v.75, p.1265-1270, 2011. Available from: $<$ http:// doi:10.1016/j.theriogenology.2010.11.040>. Accessed: Aug. 5, 2013. doi: 10.1016/j.theriogenology.2010.11.040.

ARIZA-MIGUEL, J. et al. A survey of Mycoplasma agalactiae in dairy sheep farms in Spain. BMC Veterinary Research, v.8, p.171, 2012. Available from: <https://bmcvetres.biomedcentral. com/articles/10.1186/1746-6148-8-171>. Accessed: Oct. 05, 2016. doi: $10.1186 / 1746-6148-8-171$.

AZEVEDO, A.E.O. et al. Contagious agalactia by Mycoplasma agalactiae in small ruminants in Brazil: first report. Brazilian Journal Microbiology, v.37, p.576-581, 2006. Available from: <http://www. scielo.br/scielo.php?pid $=\mathrm{S} 1517-83822006000400033 \&$ script $=$ sci arttext\&tlng=pt $>$. Accessed: Feb. 06, 2017. doi: 10.1590/S151783822006000400033

BANDEIRA, D.A. et al. Infection by Mycoplasma agalactiae in dairy goat herds in the microregionsof Cariri in ParaíbaState.
Arquivo Brasileiro de Medicina Veterinária e Zootecnia, v.60, p.1255-1258, 2008. Available from: <http://www.scielo. br/scielo.php?pid=S0102-09352008000500031\&script $=$ sci arttext\&tlng=pt $>$. Accessed: Oct. 05, 2016. doi: 10.1590/S010209352008000500031

CAMPOS, A.C. et al. ELISA protein $G$ for the diagnosticof contagious agalactia in small ruminants. Small Ruminant Research, v.84, p.70-75, 2009. Available from: <http://www. elsevier.com/locate/smallrumres>. Accessed: Jun. 26, 2017.doi: 10.1016/j.smallrumres.2009.06.006

CHAZEL, A.M. et al. Mycoplasmoses of ruminants in France: recent data from the national surveillance network. BMC Veterinary Research, v.6, p.32, 2010. Available from: $<\mathrm{https}: / /$ bmcvetres.biomedcentral.com/articles/10.1186/1746-6148-6-32>. Accessed: Jun. 24, 2017. doi: 10.1186/1746-6148-6-32.

FISCHER, A. et al. The origin of the 'Mycoplasma mycoides Cluster' coincides with domestication of ruminants. PloS ONE, v.7, p.e36150, 2012. Available from: <http://www. doi:10.1371/ journal.pone.0036150>. Accessed: Oct. 06, 2017. doi: 10.1371/ journal.pone. 0036150 .

GIL, A.M.C. et al. Genital lesions in an outbreak of caprine contagious agalactia caused by Mycoplasma agalactiae and Mycoplasma putrefaciens. Journal Veterinary Medicine B,v.50, p.484-487, 2003. Available from: <http://onlinelibrary.wiley.com/ doi/10.1046/j.0931-1793.2003.00709.x/full>. Accessed:Jun. 24 2017. doi 10.1046/j.0931-1793.2003.00709.x.

GÓMEZ MARTÍN, A.A. et al. Controlling contagious agalactia in artificial insemination centers for goats and detection of Mycoplasma mycoides subspecies capri in semen. Theriogenology, v.77, p.1252-1256, 2012. Available from: <http://doi:10.1016/j. theriogenology.2011.10.006>. Accessed: Sept. 27, 2017. doi: 10.1016/j.theriogenology.2011.10.006.

GÓMEZ-MARTÍN, A.A. et al. Contagious agalactia due to Mycoplasma spp. in small dairy ruminants: Epidemiology and prospects for diagnosis and control. Veterinary Journal, v.198, p.48-56, 2013. Available from: <http://dx.doi.org/10.1016/j. tvj1.2013.04.015>. Accessed: Sept. 27, 2017. doi: 10.1016/j. tvj1.2013.04.015.

HOSMER, A.D.W., LEMESHOW, S. Applied Logistic Regression. NewYork: Sons John Wiley, 1989.

MADANAT, A.A. et al. Contagious agalactia of sheep and goats: A review. Acta Veterinary BRNO, v.70, p.403-412, 2001. Available from: <http://www.vfu.cz/acta-vet/actavet.htm>. Accessed: Oct. 18, 2016. doi: 10.2754/avb200170040403.

MANSO-SILVÁN, L. et al. Phylogeny of the Mycoplasma mycoides cluster based on analysis of five conserved proteincoding sequences and possible implications for the taxonomy of the group. International Journal of Systematic and Evolutionary Microbiology, v.57, p.2247-2258, 2007. Available from: <http:/www.microbiologyresearch.org/docserver/fulltext/ ijsem $/ 57 / 10 / 2247$.pdf? expires $=1520354310 \& \mathrm{id}=\mathrm{id} \&$ accname $=\mathrm{g}$ uest $\&$ checksum $=$ BA7175DD55786803D444CAC48863D39E $>$. Accessed: Jan. 01, 2006. doi: 10.1099/ijs.0.64918-0.

NASCIMENTO, E.R. et al. Isolation of Mycoplasma mycoides from outbreaks of caprine mycoplasmosis in Brazil. British Veterinary Journal, v.142, p.246-257, 1986. Available from: <https://www. 
sciencedirect.com/science/article/pii/0007193586900680>. Accessed: Oct. 05, 2016. doi: 10.1016/0007-1935(86)90068-0.

NICHOLAS, R.A. Improvements in the diagnosis and control of diseases of small ruminants caused by mycoplasmas. Small Ruminant Research, v.45, p.145-149, 2002. Available from: $<$ http://www.smallruminantresearch.com/article/S0921 4488(02)00095-0/pdf>. Accessed: Jun. 24, 2017. doi: 10.1016/ S0921-4488(02)00095-0.

NICHOLAS,R.A.J. Isolation of mycoplasma ovine/caprine serogroup 11 from infertile sheep in Britain. Veterinary Record, v.145(15), p.434-435, 1999. Available from: <https://www. cabdirect.org/cabdirect/abstract/19992216189>. Accessed: Jun. 24, 2017. doi: $10.1136 /$ vr.145.15.434.

OIE (ORGANIZATION INTERNATIONAL OF EPIZOOTIES). Terrestrial Manual: ContagiousAgalactia. 2013. Available from: $<$ http://www.oie.int/en/international-standard-setting/terrestrialmanual/access-online>. Accessed: Jul. 21, 2016.

OSTROWSKI, A.S. et al. Fatal outbreak of Mycoplasma capricolum pneumonia in endangered markhors. Emerging Infectious Diseases, v.17, p.2338-2341, 2011. Available from: $<$ https://www.ncbi.nlm.nih.gov/pmc/articles/PMC3311196/ pdf/11-0187_finalD.pdf $>$. Accessed: Jul. 21, 2016. doi: 10.3201/ eid1712.110187.

PERSSON, A. et al. Diagnosis of contagious bovine pleuropneumonia by PCR laser-induced fluorescence and PCR restriction endonuclease analysis based on the 16SrRNA genes of Mycoplasma mycoides subsp. mycoides SC. Journal Clinical Microbiology, v.37, p.3815-3821, 1999. Available from: <http:// jcm.asm.org/content/37/12/3815.full.pdf + html $>$. Accessed: Oct. 5, 2016. doi: jcm.asm.org/content/37/12/3815.

PEYRAUD, A. et al. A specific PCR for the detection of Mycoplasma putrefaciens, one of the agents of the contagious agalactia syndrome of goats. Molecular and Cellular Probes, v.17, p.289-294, 2003. Available from: $<$ https://www.sciencedirect. com/science/article/pii/S0890850803000732>. Accessed: Jan. 01, 2006. doi: 10.1016/j.mcp.2003.07.006.

RAZIN, S.;TULLY, J.G. Molecular and diagnostic Procedures in Mycoplasmology. California:Academic Press, 1996.

SILVA, A.N.S. et al. Congenital infection by Mycoplasma agalactiae in goat kids. Arquivo Brasileiro de Medicina Veterinária e Zootecnia, v.66, p.631-634, 2014. Available from: <http://www.scielo.br/scielo. php?pid=S0102-09352014000200044\&script=sci_arttext\&tlng=pt $>$. Accessed: Feb. 27, 2015. doi: 10.1590/1678-41626625

TOLA, A. et al. Detection of Mycoplasma agalactiae in sheep milk samples by polymerase chain reaction. Veterinary Microbiology, v.54, p.17-22, 1997. Available from: <https://www.sciencedirect. com/science/article/pii/S0378113596012692>. Accessed: Jan. 01, 2006. doi: 10.1016/S0378-1135(96)01269-2.

WHITFORD, H.W. et al. Mycoplasmosis in Animals: Laboratory Diagnosis. Iowa S.:AmesUniversityPress, 1994. 